\title{
Analysis on Financial Environment of China Investing in Myanmar's transport infrastructure
}

\author{
Wenhong Shen* \\ International Business School \\ Yunnan University of Finance and Economics \\ Kunming, China \\ Swhong0214@163.com \\ Guangyu Li \\ International Business School \\ Yunnan University of Finance and Economics \\ Kunming, China \\ Lgyu920@outlook.com
}

\author{
Ersi Liu \\ International Business School \\ Yunnan University of Finance and Economics \\ Kunming, China \\ Liuersi309@126.com \\ Ke Yan \\ International Business School \\ Yunnan University of Finance and Economics \\ Kunming, China
}

\begin{abstract}
- with the presenting of "one belt one road" and establishing of Asian Infrastructure Investment Bank, Myanmar's transport infrastructure has become the focus of investment. At the same time, financial risks are also needed to be aware of in the process of investment. After analysis Myanmar's domestic financial environment, concluded the financial environment will gradually be improved in Myanmar with the acceleration of Myanmar's economy and financial reforming. That will provide more favorable financial security for foreign tradesman to invest in Myanmar's transportation infrastructure.
\end{abstract}

Keywords-Myanmar; transportation infrastructure; financial environment

\section{INTRODUCTION}

Transportation requires intensive capital investment, it is a typical capital-intensive industries. Its construction always needs a huge investment. In the process of cooperation of Chinese enterprises and Mekong Subregion countries such as Myanmar, Laos and Vietnam will face a variety of risks, the most worthy of attention is the risk of financial distress. But there is almost any scholars study the financial of Myanmar's transport infrastructure. Just several scholars study the present situation of Myanmar.

The representative foreign scholars study Myanmar's financial is Reinhart in the University of Maryland researched the history of Myanmar's exchange. Reinhart sorted the history of Myanmar's exchange rate, in particular from pegged to the pound in period of British colonial to dual exchange rate system in 2011. Myanmar's exchange rate regime is pegged to the US dollar for a long time, within a certain range free-floating exchange rate system. Foreign Scholars only focused on one particular aspect of Myanmar financial. They did not do research on Myanmar's transport infrastructure [1].
Domestic scholars, just Jinbao Zhang studied the financial risk of foreign businessman investing in Myanmar. But this article did not connect financial with Myanmar's transport infrastructure [2].

Although there is little document literature about Myanmar's financial environment which connect with Myanmar's transport infrastructure, we could refer to article which tell us how to analyze financial environment for foreign businessman. $\mathrm{Lu} \mathrm{Li}$ pointed that financial institutions, financial markets, financial supervision and financial instruments constitute the financial environment system for the development of venture capital [3]. Thus, we could analyze financial environment from these aspects. Binxi Shen pointed that financial environment include law, policy, credit culture, and many other aspects [4]. These external conditions could ensure the smooth progress of financial activities. Bing Zhou et al. confirmed the financial environment as a crucial factor directly restricts the industrial agglomeration and FDI Spillover Effect. At the same time, this paper also reveals the financial environment as an important factor in the promotion of industrial agglomeration which could effectively play a middle conduction effect and promote industrial agglomeration [5].

Therefore, know about financial environment in Myanmar and other countries, emphasis on the analysis of host countries' environment financial, is practical and urgent task in front of Chinese enterprises. Then this article will analyze the advantages and disadvantages of Myanmar's domestic financial environment which connect with the construction of Myanmar's transport infrastructure. And this paper will from financial institution, financial market, financial credit and policy to analyze Myanmar's financial environment which connect with Myanmar's transport infrastructure. 


\section{The Situation OF CHINA INVEST IN MYANMAR's TRANSPORT INFRASTRUCTURE}

From the year 2010 to 2014, investment in Myanmar's transport infrastructure growth $6.7 \%$ on average annual, following $7.1 \%$ in Laos. But investors are mainly from Indonesia, Thailand, Malaysia and Singapore. China are not included. The total investment in transport infrastructure in Southeast Asia will up to $\$ 32$ billion in five years. Because of lacking public investment, it will attract private capital to enter the field.

The Asian Development Bank estimates that, in order to develop Myanmar's backward transportation infrastructure, 60 billion dollars will be needed to invest in Myanmar from 2016 to 2030. This requires government to increase investment in the transport sector to $3 \%-4 \%$ of GDP from around $1 \%$. It is estimated that after the large-scale investment complete the development of transport industry, transportation expenses will down to $3 \%$ from the peak. At present, Myanmar still do not well in developing public transport. Most of the road network needs to be upgraded. Adequate transport infrastructure will play an important role in the development of the national economy by promoting business links among nationals and foreign investors.

It can be seen from the above, there is a large space in Myanmar to develop transportation infrastructure. Therefore, China has big opportunity to develop transport infrastructure in Myanmar. In order to help Chinese enterprises to seek better development in Myanmar's transport infrastructure, the study of the financial environment in Myanmar is particularly important for Chinese enterprises.

\section{ANALYSIS ON FINANCIAL ENVIRONMENT IN MYANMAR}

Myanmar has taken a series of measures in the financial sector. These reform measures in financial areas are conducive to Chinese enterprises to invest in transport infrastructure sector. But there are still negative factors cannot be ignored in financial environment in Myanmar for Chinese enterprises.

\section{A. Favorable Factors of Financial Environment in Myanmar}

\section{1) Yangon Stock Exchange opened}

Yangon stock exchange was conducted as a joint venture by the Treasury under the Myanmar Economic Bank, Daiwa Securities and Tokyo Stock Exchange. Myanmar accounted for 51\% shares; Daiwa Securities shares accounted for 30.25 percent, the Tokyo Stock Exchange held the left $18.75 \%$ stake. After the agreement signed in 2014 between Myanmar and Japan, the opening time of Yangon Stock Exchange has delayed many times. Eventually, it opened in the end of 2015. Currently, Yangon Stock Exchange will only accept investors to open an account temporarily. All transactions will be limited to kyat in Myanmar's largest private bank --KBZ Bank settlement.

\section{2) Banking Financial Institutions in Myanmar}

The reform of Myanmar's financial sector break the situation that monopolized by the state banking. Banking system includes state-owned banks, state and private joint venture, private and foreign operators. Up to March 2012, Myanmar has opened four state-owned banks and 20 private banks. The main private banks are: Myawadi Bank, Gan Bozha Bank, Co-operative Bank, Irrawaddy Bank, Asia Green Development Bank, Yoma Bank, Universal Bank and Oriental Bank.

TABLE I. MYANMAR BANKING INSTITUTIONS IN 2015

\begin{tabular}{|l|l|}
\hline \multicolumn{1}{|c|}{ Bank Name } & \multicolumn{1}{|c|}{ Main Duty } \\
\hline Central Bank & $\begin{array}{l}\text { Stable kyat value at home and abroad. Formulate } \\
\text { and implement monetary policy }\end{array}$ \\
\hline $\begin{array}{l}\text { Myanmar } \\
\text { Economic Bank }\end{array}$ & $\begin{array}{l}\text { Accept current and short-term deposits; handling } \\
\text { savings bank deposits and savings single issue; } \\
\text { issuing all kinds of loans, pensions, bills of } \\
\text { exchange and promissory notes sales }\end{array}$ \\
\hline $\begin{array}{l}\text { Myanmar } \\
\text { Commertment and } \\
\text { Bank }\end{array}$ & $\begin{array}{l}\text { According "Foreign Investment Law", "Citizens of } \\
\text { Myanmar Investment Law" to raise funds for the } \\
\text { investment, to provide the necessary domestic and } \\
\text { international banking services for the development } \\
\text { of the private economy }\end{array}$ \\
\hline $\begin{array}{l}\text { Myanmar } \\
\text { Foreign Trade } \\
\text { Bank }\end{array}$ & $\begin{array}{l}\text { Mainly engaged in foreign trade business related to } \\
\text { banking }\end{array}$ \\
\hline $\begin{array}{l}\text { Myanmar } \\
\text { Ruriculture and } \\
\text { Development } \\
\text { Bank }\end{array}$ & $\begin{array}{l}\text { Paying short-term and long-term loans to farmers } \\
\text { per year for the development of domestic } \\
\text { agriculture and animal husbandry, the prosperity } \\
\text { and progress of the local economy and society }\end{array}$ \\
\hline Foreign Banks & $\begin{array}{l}\text { New Bank of South Australia, Bangkok Bank, } \\
\text { Mitsubishi Tokyo UFJ Bank, ICBC, Malaysian } \\
\text { bank, Mizuho Bank, OCBC Bank, Sumitomo } \\
\text { Mitsui Banking Corporation, Singapore's United } \\
\text { Overseas Bank }\end{array}$ \\
\hline
\end{tabular}

\section{3) Reform of Exchange Rate in Myanmar}

In terms of reforming of exchange rate, Myanmar will focus on improving the confusion of exchange rate in investment market. At present, official is gradually reducing the exchange rate of kyat against the U.S. dollars. That makes official exchange rate move closer to market exchange rates. At present, the difference is less than $1 \%$. Some domestic banks and foreign banks that get licenses have begun forwards and swaps transactions.

For a long time, Myanmar takes official, semi-official, non-official and black market exchange rates. In the period of military government, Myanmar currency links to basket currencies of IMF Special Drawing Rights which is set at 6.4 kyat to one U.S. dollar. But on the black market, one U.S. dollar can exchange more than 640 kyat. Since 2012, the Central Bank of Myanmar implements limited floating exchange rate policy. At first, the daily exchange rate is set at 818 kyat to one U.S. dollar. Every morning, commercial banks will put their auction price of kyat in the auction. The Central Bank will announce a daily reference exchange rate according to bid price. Commercial banks can trade kyat at plus or minus $0.8 \%$ based on this reference rate. To improve profits, the commercial banks will use unofficial rate that is more competitive in private transactions.

4) Taking Sovereign Credit Rating 
About credit rating, Myanmar is also trying to achieve "breakthrough." 2015, Myanmar authorized Citibank and Standard Chartered Bank to provide advice for its first sovereign credit rating. Myanmar is expected to complete the related work in mid-2016. If Myanmar can get sovereign credit rating of Fitch, Standard \& Poor's or Moody's and other international organizations, it can be sold to international investors.

Since liberalized economic, financial sector is expected to be developed in Myanmar. It has a strong attraction for international investors. According to the IMF forecast, the growth of Myanmar's GDP is expected to reach $8.4 \%$ in this year. It will become the fastest growth economy of the world. Meanwhile, the opening of Myanmar Stock Exchange, more perfect banking system and the reforming will make financial services more perfect. This is extremely beneficial for Chinese enterprises to invest in the transport infrastructure in Myanmar.

\section{B. Unfavorable Factors of Financial Environment in Myanmar}

Although Myanmar carried out financial reforms, the infrastructure of financial sector in Myanmar is relatively backward. Financial services industry has a larger gap compared with developed countries in depth and breadth of financial services.

\section{1) Small Overall Size of Financial Sector}

Myanmar has a small scale of financial sector. There is only less than $1 \%$ companies among 40,000 small and medium enterprises that registered in Myanmar use government loans that provided by SME development banks. Myanmar government began to provide loans for SMEs in 2012. Each province and Naypyidaw have the loan amount. But up to May 1, 2015, just more than 300 small and medium enterprises use the loan. As is shown in Myanmar official statistics, up to March 1, 2015, there are 237 times loans with a total amount of 6.9 billion kyats at $8.5 \%$ interest rate. Financial services cannot meet the needs of the Myanmar people.

\section{2) Unstable Domestic Interest Rates}

Myanmar Economic Bank which is the largest stateowned bank in Myanmar, whose interest rates have doubled in the first six months of fiscal 2015. Myanmar Economic Bank has 307 branches at a loss all year round. Its deficit was covered by the Central Bank of Myanmar. In fiscal 2015 , because of the increase of interest, banks require an additional budget of 33.79 billion kyat to pay interest, 42.117 billion kyat for the daily operation and other expenses.

Myanmar Economic Bank offers banking services in rural areas, and provide highly subsidized loans to Myanmar Agricultural Development Bank and other state-owned banks. Its lending rate is about $4 \%$ lower than the $8 \%$ of deposit interest, thus resulting in a net loss. Regardless of loans that given to Myanmar Agricultural Development, the loan to deposit ratio of Myanmar Economic Bank is about $80 \%$. The measures that reduce the liquidity by buying treasury bonds is not sustainable. The correct approach is to modernize state-owned banks and policy banks.

3) Low Level of Risk Management of Commercial Banks

Myanmar lacks high-level financial professionals, has lower level of banking risk management. Myanmar has not yet adopted the international advanced risk management methods and advanced regulatory standards. The realistic operating conditions of banks in Myanmar are: First, the requirements of statutory minimum capital of banks in Myanmar are low, as long as 30 million kyat. To some extent, it reduced the banks' ability to resist risks; second, the clearing system of commercial bank is underdeveloped with low level of computerized accounting. Many banks still remain manual bookkeeping. The operating costs of the banks is relatively high which reduced the profit margins; third, lending rates of banks in Myanmar are high, maintained between $15 \%$ and $30 \%$. Higher lending rates increased the likelihood of loan defaults objectively. Overall, the low level of risk management of commercial banks in Myanmar and poor management conditions may affect the financial security of the project.

\section{PREVENTION AND COUNTERMEASURES FOR MYANMAR FINANCIAL RISK FACTORS}

Standing Chinese business point of view, the risk of the financial sector can be divided into direct and indirect risk. Exchange rate risk, inflation risk, foreign exchange control, direct indirect risks such as the risk companies face is from the macro-economic development situation, the economic and financial policies of the uncertainty of the enterprise risk of indirect effects caused.

\section{A. Prevention and Countermeasures for direct risk}

First, the multi-enterprise can be a means of financing, to reduce the interest rate risk in Myanmar. Carefully selecting domestic banks to ensure the safety of funds. Second, it can be used to purchase commercial insurance companies bear the transfer of risk. Third, consider the phased implementation of the project, the benefits of pre-project (kyat) as late into the project. This is to avoid pre-project profits remitted regulation to some extent, also avoid blindly increase the risk of pre-investment brings. Fourth, we can consider the profits of some items purchased Myanmar scarce commodity, for hedging risk. For example, Myanmar iron ore, zinc, manganese, nickel, etc., in the form of export trade will be part of the profit repatriation to Myanmar. Fifth, investment business, if investment in production of products for export, it might consider production in Myanmar and overseas settlement methods in overseas trading, to avoid foreign exchange controls.

\section{B. Prevention and Countermeasures for indirect risk}

Due to the risk of economic and financial policies and the economic environment, companies are generally difficult to control. Under favorable conditions, we can exert some influence (such as seminars financed economic and financial policies and investment companies or closely related forums, etc.) through the appropriate channels for policy formulation. 
Taking into account the economic and financial situation in Myanmar which is changing, and adding timely follow-up analysis, we can enhance the predictability of situation development.

\section{SUMMARY AND OUTLOOK OF FINANCIAL ENVIRONMENT OF MYANMAR TRANSPORTATION INFRASTRUCTURE}

\section{A. Summary}

2014 by the Economist Group's EIU (Economist Intelligence Unit) risk rating agency announced the risk rating in the case show that Myanmar Investment financial risk score of 71 , class D. (Note: The evaluation of each indicator were set five grades $\mathrm{A}$ to $\mathrm{E}$, where $\mathrm{A}$ is 0 , indicating minimal risk, E 100 points, represents the greatest risk) This means China direct investment in Myanmar companies face greater risks, especially transport infrastructure industry requires intensive capital investment, is a typical capital-intensive industries, the construction investment is often enormous.

However, since the political transition and economic openness, Burma to speed up the pace of opening up the financial sector, the financial sector has taken a series of measures for the new Foreign Investment Law liberalized foreign-invested enterprises in the banking and insurance business made a positive limit of supporting policies ready. These areas of financial reform measures, such as improving the domestic securities market or the reform of exchange rate system, are conducive to Chinese enterprises to invest in Myanmar transport infrastructure sector.

\section{B. Outlook}

Myanmar in recent years, had rapidly economic development, GDP also increased year by year. Foreign trade and attract foreign investment credits also increased year by year, while the government of Myanmar carried out a series of economic reforms, and promote the further development of the Myanmar economy. However, Myanmar's economic development is still at a low level, the economy and the financial sector, poor infrastructure conditions adversely transport infrastructure investment projects. Myanmar's economic development now are in a transition period, as Myanmar's economy and to accelerate the pace of financial reform, these adverse conditions will gradually improve.

Myanmar future financial industry outlook is positive. On objective conditions, the potential to Burma's natural resources and human resources capable of supporting rapid economic growth, the financial industry standardization and systematization upgrade is imminent. Secondly Myanmar new government has relatively strong economic growth will, the government will give priority to the development of 10 areas of infrastructure, trade and investment, the private economy, health and education, the expected future economic and financial reforms will be more open to further stimulate foreign investment vibrant transport infrastructure industry, but also to provide a more favorable financial preparedness and protection for foreign investment in the transportation infrastructure sector.

\section{ACKNOWLEDGMENT}

I am greatly indebted to my thesis supervisor, Professor Ersi Liu. Without his patient assistance and friendly encouragement, it would not be possible for me to complete this thesis. My sincere thanks should also go to all my teachers for their scholarly advice and generous help during my study in YNUFE.

\section{REFERENCES}

[1] K. Tomoko, "Rural Credit Markets in Myanmar: A Study of Formal and Non-Formal Lenders," Asian Journal of Agriculture and Development, vol. 4, 2009, pp. 32-37.

[2] J.B. Zhang, "Analysis on Myanmar's economic and financial Risks for Foreign investment," Forward Position, vol. 17, 2013, pp. 101104.

[3] L. Li, "Analysis of Financial Environment of Risk Investment," Manager' Journal, vol. 6, 2011, pp. 23.

[4] B.X. Shen., "Efforts to improve the financial environment," Journal of Financial Research, vol. 7, 2004, pp.33-39.

[5] B. Zhou, Q. Zhang, C.Y. Zhang, "FDI and industrial agglomeration under the background of financial environment factors," Management World, vol. 1, 2012, pp. 172-173.

[6] Z.L. Li, "Myanmar's New Foreign Investment Law brings opportunities and challenges for foreign Investors," China Chief Financial Officer, vol. 8, 2013, pp. 69-71.

[7] D. Xiao, "Present Situation and Problems of Chinese enterprise investment in Myanmar," Guangdong: Jinan University, 2014, pp. 1721.

[8] I. Ethan, Carmen M. Reinhart, and Kenneth S. Rogoff, "The Country Chronologies and Background Material to Exchange Rate Arrangements into the 21st Century: Will the Anchor Currency Hold," 2011.

[9] C. Robert, and Merton, "A Functional Perspective of Financial Intermediation," Financial Management, vol. 24, 1995, pp. 23-41.

[10] R.J. Zhao, and X.F. Wang, "Myanmar's Economic Development and Its Latent Crisis," All-round Southeast Asia, 2004, pp. 25-27.

[11] J.H. Zhou, "Review of financial cooperation between China and Myanmar," Times Finance, vol. 9, 2013, pp. 16-19.

[12] J.H. Zhou, and Y.Q. Tan, "On the current situation of financial cooperation between China and Myanmar," Times Finance, 2013, pp. 15-18. 